\title{
PRESENCE OF ANTIBODIES AGAINST Leptospira spp. IN DOGS OF UBERLANDIA, MG, BRAZIL
}

\author{
PRESENÇA DE ANTICORPOS CONTRA Leptospira spp. EM CÃES NO MUNICÍPIO \\ DE UBERLÂNDIA, MG, BRASIL
}

\author{
Jacqueline Ribeiro de CASTRO ${ }^{1}$; Mariana Assunção de SOUZA ${ }^{1}$; \\ Antônio Bertolino Cardoso NETO ${ }^{2}$; Rafael Quirino MOREIRA ${ }^{1}$; \\ Sandra Renata Sampaio SALABERRY ${ }^{1}$; Ednaldo Carvalho GUIMARÃES ${ }^{3}$; \\ Anna Monteiro Correia LIMA ${ }^{1}$ \\ 1. Laboratory of Contagious Infectious Diseases, Faculty of Veterinary Medicine, Federal University of Uberlândia, \\ Uberlândia, MG, Brazil. jack_ufu@hotmail.com.br ; 2. Post graduate Program in Veterinary Science, UFU, Uberlândia, MG, Brazil; 3. \\ Professor Faculty of Mathematics UFU, Uberlândia, MG, Brazil.
}

\begin{abstract}
The aim of this study was to investigate the occurrence of antibodies against Leptospira spp. and risk factors related to the epidemiology of leptospirosis in dogs living in the urban area of the municipality of Uberlandia, Minas Gerais, Brazil. Blood serum samples were examined from 268 dogs from the municipality's North, South, East, West and Central sanitary districts. The samples were collected during an animal vaccination campaign against rabies in August 2008. The occurrence of antibodies against specific leptospiral serovars was determined by the microscopic agglutination test (MAT). Multivariable logistic regression was used to evaluate the association between sex, age, previous vaccination, habitation, presence of rats, and history of human and/or animal leptospirosis on the occurrence of infection. The occurrence of canine leptospirosis was $28.36 \%$ (76/268), the most prevalent serovars were: Autumnalis $(34.21 \%)$, Tarassovi (23.58\%), Canicola (17.11\%) and Grippotyphosa $(14.47 \%)$. No risk factors were found to be statistically significant ( $p>0,05$ for all examined variables). The fact that close to $30 \%$ of dogs showed evidence of past infection with Leptospira points to the need for the adoption of preventive measures, as the disease may represent a public health risk.
\end{abstract}

KEYWORDS: Dogs. Leptospira interrogans. Microcopic Agglutination Test.

\section{INTRODUCTION}

Leptospirosis is a highly prevalent zoonotic disease among domestic and wild animals and humans. This zoonotic disease is endemic in Brazil due to climate conditions, such as temperature, humidity and rainfall, favorable to expect this bacterium in the environment. Maintenance of Leptospira in the environment is also supported by the country vast rodent populations (BRASIL, 1995).

Among domestic animals, dogs have an important role in the epidemiology of the disease and are considered as maintenance host of a number of Leptospira serovars and the infection may cause a mild course or may not cause any symptoms. Thus acting as reservoir hosts that eliminate the bacterium into the environment through the persistent or transient shedding of Leptospira in the urine and may constitute a health hazard for human and livestock (LANGONI et al., 2002). The serovars commonly associated with canine leptospirosis are Canicola and Icterohaemorrhagiae, but others such as Copenhageni and Autumnalis have become more apparent in the population of domestic animals (MELLO; MANHOSO, 2007).
Several seroepidemiological studies on canine leptospirosis have been conducted in various regions of the world, including Brazil. However, due to constant changes in the environment, the natural hosts and in the etiology itself of the disease, is necessary constant research on serovars prevalent and the risk factors associated with the study area. Thus it becomes possible to operate with control measures and prophylaxis according to each situation (BOLIN, 1996).

In view of the lack of regional epidemiologic data and the zoonotic nature of this disease the present study aimed to investigate the occurrence of antibodies against Leptospira spp. and risk factors related to the epidemiology of leptospirosis in dogs living in the urban area of the county of Uberlandia, Minas Gerais, Brazil.

\section{CONTENTS}

The study was carried out in the municipality of Uberlandia, located in the region known as the Triângulo Mineiro in the state of Minas Gerais, Brazil. The region's climate is tropical, with an annual rainfall of $1500 \mathrm{~mm}$ and an average temperature of $22^{\circ} \mathrm{C}$ (BRITO; PRUDENTE, 2005). 
Sampling was performed in August 2008 during the $26^{\text {th }}$ urban vaccination campaign against animal rabies. The sample size was determined based on Simple Random Sampling, a confidence level of $95 \%$, and an acceptable error of about $5 \%$ (THRUSFIELD, 2004). The expected prevalence was $26 \%$ that corresponds to the average prevalence of canine leptospirosis in Brazil, according to Boechar and Machado (2004).

The informations about the vaccination posts was provided by the Zoonosis Control Center (ZCC) of Uberlandia's municipal health department. The blood collection schedule and locations were selected randomly. Blood samples were collected from dogs at 60 of the 300 permanent vaccination posts distributed in the municipality's five sanitary districts: Central, North, East, West and South.

For the serological examination of past Leptospira infection, $5 \mathrm{ml}$ of blood were drawn from the accessory cephalic vein. The samples were refrigerated $\left(2^{\circ} \mathrm{C}\right.$ to $\left.8^{\circ} \mathrm{C}\right)$. The material was then taken to the Laboratory of Infectious Contagious Diseases at the School of Veterinary Medicine of the Federal University of Uberlandia (FAMEVUFU). The serum samples were stored at $-20^{\circ} \mathrm{C}$ until they were tested with the microscopic agglutination test (MAT), according to Brasil (1995) and Magalhães et al. (2006).

The test was performed according to the Brazilian Ministry of Health with the aid of a set of 12 strains that included the serovars Autumnalis, Australis, Bataviae, Bratislava, Canicola, Grippotyphosa, Hardjo, Hebdomadis, Icterohaemorrhagiae, Pomona, Tarassovi and Wolffi. A titer of 1:100 was considered positive. The seroreactive samples were then titrated up to $1: 3200$, diluted in a geometrical ratio of two. In the case of coagglutination the serovar with the highest titer was considered reactive.

An epidemiological investigation was carried out, involving the application of a questionnaire to evaluate risk factors inherent to the occurrence of the infection. The variables investigated as possible risk factors for the occurrence of the infection were sex, age, vaccination history, habitation, access to the street, presence of rodents, and the past occurrence of animal and/or human leptospirosis in the household.

The descriptive statistics was made to obtain frequency of serovars and coagglutination rates from different serovars for Leptospira spp. Odds ratio test was applied to identify correlations between the occurrence of seropositive (for Leptospirosis) animals and hypothetical risk factors, tested with 0.05 as the level of significance, using BioEstat 5.0 software (AYRES et al., 2007). The significance of odds ratio was assessed by WALD test.

The experiment was conducted according to the rules of and pursuant to the approval (015/08) of the Animal Ethics Committee of the Federal University of Uberlandia, MG, Brazil. The results indicated a mean seroprevalence of $28.36 \%$ (76/268). The serovars found with the high frequency were Autumnalis (34.21\%), Tarassovi (23.68\%), Canicola $(17.11 \%)$ and Grippotyphosa $(14.47 \%)$ with titers that varied from 100 to 3200 (Table 1). None of the dogs showed evidence of prior infection with serovars Hebdomadis, Bataviae or Hardjo.

The variables of age, previous vaccination, habitation, access to the street, presence of rodents, vacant lots, and a history of animal and/or human leptospirosis were not significant risk factors in the odds ratio analysis $(\mathrm{p}>0.05)$.

Table 1. Frequency of serovars in 76 serum samples of seropositive dogs living in Uberlandia, MG, 2008.

\begin{tabular}{lcc}
\hline \multicolumn{1}{c}{ Serovar } & $\begin{array}{c}\text { Seropositive dogs } \\
\text { Absolute frequency }\end{array}$ & $\begin{array}{c}\text { Percentage frequency } \\
(\%)\end{array}$ \\
\hline Autumnalis & 26 & 34.21 \\
Tarassovi & 18 & 23.68 \\
Canicola & 13 & 17.11 \\
Grippotyphosa & 11 & 14.47 \\
Bratislava & 3 & 3.95 \\
Icterohaemorragiae & 2 & 2.63 \\
Australis & 1 & 1.32 \\
Pomona & 1 & 1.32 \\
Wolffi & 1 & 1.32 \\
\hline Total & 76 & 100.00 \\
\hline
\end{tabular}

${ }^{1}$ Dogs with titers to more than one serovar were counted based on the highest titer. 
The high prevalence of Leptospira infection in dogs indicates that it is a common infection in the municipality of Uberlandia and is probably underestimated due to the large number of chronically affected animals without clinical signs. The dogs involved in the present study did not show clinical signs of the disease and were probably nonsymptomatic hosts of the bacterium, acting as reservoirs of the disease and able to infect humans, thus maintaining the epidemiological chain of infection.

The seroprevalence of canine leptospirosis in the county of Uberlandia has correlation with studies realized in other parts of Brazil showing a variation of $13.1 \%$ to $34.8 \%$ with and average prevalence of canine leptospirosis of $26 \%$ according to Boechar and Machado (2004). The differences in the percentage of positivity are probably due to the variety of factors that influence the occurrence of leptospirosis, such as topography, temperature, humidity, rainfall, domestic reservoirs, wild reservoirs, and differences in the canine populations studied (BATISTA et al., 2005).

The cases of coagglutination verified in this study, $(19.73 \%)$ could be attributable to crossreactivity among Leptospira spp. serovars. However co-infections hypothesis should not be discarded. The cases of simultaneous infection by more than one serotype can be explained by the animals' exposure to more than one serovar and to a range of different reservoirs and environments (BARWICK et al., 1998).

The higher incidence of the serovar Autumnalis $(35.53 \%)$ coincided with the findings reported by Batista et al. (2004), Aguiar et al. (2007) and Azevedo et al. (2011) that found 20\%, 22.2\% and $13.16 \%$ respectively, of dogs seropositive for Autumnalis. Aguiar et al. (2007) stated that the presence of uncommon serovars can be explained by different animal species sharing the same habitation, which can promote the association and adaptation of agents to new hosts. Azevedo et al. (2011) reported in his study that the risk factor for canine leptospirosis was the contact with caprine/ovine.

Of the total of $26 \mathrm{dogs}$, reactive from serovar Autmnalis 16 received the immunization against Leptospira spp. therefore its occurrence was higher in vaccinated dogs. This finding light is important since there is no cross-immunity between serovars and most vaccines of canine leptospiosis present in the market are composed primarily by serovars Canicola, Icterohaemorrhagiae, Grippotyphosa and Pomona (AZEVEDO et al., 2011). The occurrence of serovar Autumnalis reinforces the observations made by Viegas et al. (2001) and Fernandes et al. (2013), that the occurrence of serovars Icterohaemorrhagiae and Canicola been decreasing, probably due to high percentage of vaccinated animals.

The results of the statistical analysis of odds ratio about the various potential risk factors shows that none of the variables including sex, age, habitation, vaccinated, leptospirosis previous diagnosed, presence of rodents, vacant lots and access to the street were associated with seropositivity in the MAT $(\mathrm{p}>0.05)$.

Among the 268 dogs included in study, 110 were males and 158 females of different breeds and ages. The males showed $31.81 \%$ of seropositive while the females showed $25.94 \%$. In this study, the variable of sex was not identified as a risk factor for infection by Leptospira spp. like Batista et al. (2004) who did not find sex-related differences. However, Silva et al. (2006) and Aguiar et al. (2007) found an unexpected male predisposition to infection by Leptospira spp. which was attributed to the social behavior of this sex, which has stronger reproductive urges than females and may also have greater access to the street and hence to pathogen exposure.

Although none risk factor were significant Silva et al. (2006) and Querino et al. (2003) argue that access to the street is an important risk factor for canine leptospirosis, since it provides countless possibilities for infection through direct and indirect contact with other animals or access to flooded areas. Moreover, according Querino et al. (2003), the habit of hunting rodents and the existence of marshy areas close to residences were considered risk factors for the occurrence of canine leptospirosis.

With regard to the vaccination protocol, only 18 dogs $(6.72 \%)$ received the multivalent vaccine composed of the serovars Icterohaemorrhagiae, Grippotyphosa, Canicola and Pomona. Only two of these dogs had been subjected to the vaccination protocol combined with vaccination against canine influenza and giardiasis. We identified 56 dogs (20.89\%) immunized with the bivalent vaccine against Canicola and Icterohaemorrhagiae, while 194 dogs $(72.38 \%)$ had not received any type of immunization against Leptospira spp.

Of the total of 268 dogs, $74(24.61 \%)$ had received some type of immunization against Leptospira spp. at some point in their lives, although it was not known when this immunization occurred, thus preventing us from distinguishing between 
antibodies due to post-vaccination or to natural infection.

Among the 76 seroreactive dogs, 46 $(60.52 \%)$ had received some type of vaccination against Leptospira interrogans while 30 (39.48\%) had never been immunized against the disease. This may be explained by the fact that vaccinated animal may come into contact with serovars that are not contained in the vaccine, and may thus become infected. Moreover, vaccination reinforcements may have been given at improper time intervals, since the period elapsed between the last vaccination and the blood sampling was not taken into account (JASZCZERSKI, 2005).

The presence of rodents in the dog's habitation was observed in $59.20 \%$ of the cases, and vacant lot and suitable shelter for rats in $63.15 \%$. Fernandes et al. (2013), reported that the presence of rodents can be a significant risk factor since serovars maintained by these animals were identified in his work among the seropositives dogs. The type of habitation in which the dogs lived was predominantly urban residences, since the study was performed in the urban perimeter of the municipality. In a study carried out by Aguiar et al. (2007), rural dogs showed higher seropositivity than urban dogs. However in this work, the type of housing of dogs, urban or rural, was not considered a risk factor for leptospirosis, as also verified by Querino et al. (2003).

The dogs ranged in age from five months to 15 years, with males showing an average age of four years (SD: 3.7) and females of three years (SD: 2.1). In the present study, age was not considered a significant risk factor for the occurrence of canine leptospirosis, contrary to the findings of Batista et al. (2005) and Aguiar et al. (2007), who reported a higher number of seropositive dogs older than one year. Silva et al. (2006) reported a higher occurrence of the disease in dogs older than five years. This is likely due to the fact that older animals have had more time to enter into contact with the etiologic agent. Moreover, puppies receive more attention from their owners, resulting in lower incidences of the disease in this age group.

Among the dogs evaluated, 153 (57.08\%) presented age $\leq 1$ year and vaccinated young animals may have antibodies against the vaccine. MAT reactive antibodies in vaccinated animals last and this could explain seroreactivity in this age group.

We concluded that the infection with Leptospira spp. is present in dogs of Uberlandia and the occurrence of the disease is a warning for the zoonotic potential of canine leptospirosis. The most prevalent serological responses were to serovars Autumnalis, Tarassovi, Canicola and Grippothyphosa, indicative of its importance in the sampled dogs. Although the risk factors for leptospirosis in this study were not statistically significant as determinants of disease, its suggested that its occurrence in the county may be related to the uncontrolled growth of urban centers, with poor sanitation and consequent proliferation of animals carriers of leptospiras.

For the control of leptospirosis it's recommended the implementation of an appropriate public health program, based on hygienic practices, vaccination against serovars found in each region and early diagnosis to an appropriate treatment and eradication of renal carrier.

RESUMO: O objetivo deste estudo foi investigar a ocorrência de anticorpos contra Leptospira spp. e os fatores de risco relacionados à epidemiologia da leptospirose em cães que vivem na área urbana do município de Uberlândia, Minas Gerais, Brasil. Amostras de soro foram examinados a partir de 268 cães dos distritos sanitários Norte, Sul, Leste, Oeste e Central. As amostras foram colhidas durante a campanha de vacinação contra a raiva animal em agosto de 2008 . A ocorrência de anticorpos contra sorovares específicos foi determinada pelo teste de Soroaglutinação Microscópica (SAM). Foi utilizada a regressão logística multivariada para avaliar a associação entre sexo, idade, a vacinação, habitação, presença de ratos e história de humanos e/ou leptospirose animal na ocorrência da infecção. A ocorrência da leptospirose canina foi de 28,36\% (76/268), os sorovares mais prevalentes foram: Autumnalis $(34,21 \%)$, Tarassovi (23,58\%), Canicola $(17,11 \%)$ e Grippotyphosa $(14,47 \%)$. Quanto aos fatores de risco analisados, não foi encontrada diferença estatística significativa ( $p>0,05$ para todas as variáveis analisadas). O fato de $30 \%$ dos cães terem apresentado evidência de infecção causada por Leptospira aponta para a necessidade da adoção de medidas preventivas, pois a doença pode representar um risco para a saúde pública.

PALAVRAS-CHAVE: Cães. Leptospira interrogans. Soroaglutinação Microscópica 


\section{REFERENCES}

AGUIAR, D. M.; CAVALCANTE, G. T.; MARVULO, M. F. V.; SILVA, J. C. R.; PINTER, A.; VANCONCELLOS, A. S.; MORAIS, Z. M.; LABRUNA, M. B.; CAMARGO, L. M. A.; GENNARI, S. M. Fatores de risco associados à ocorrência de anticorpos anti-Leptospira spp. em cães do município de Monte Negro, Rondônia, Amazônia Ocidental Brasileira. Arquivo Brasileiro de Medicina Veterinária e Zootecnia, Belo Horizonte, v. 59, n. 1, p. 70-76, 2007. http://dx.doi.org/10.1590/S0102-09352007000100012

AZEVEDO, S. S.; FERNANDES, A. R. F.; QUEIROGA, I. M. B. N.; ALVES, C. J.; MORAIS, Z. M.; SANTOS, C. S. A. B.; VASCONCELLOS, S. A. Ocorrência e fatores de risco associados à leptospirose em cães atendidos em hospital veterinário no semiárido paraibano. Brazilian Journal of Veterinary Research and Animal Science, São Paulo, v. 48, n. 2, p. 161-166, 2011.

AYRES, M.; AYRES, J. R. M.; AYRES, D. L.; SANTOS, A. A. S. Bioestat 5.0: Aplicações estatísticas nas áreas das ciências biomédicas. $6^{a}$ ed., Belém: IDSM/MCT/CNPq, 2007. 364p.

BARWICK, R. S.; MOHAMMED, H. O.; MCDONOUGH, P. L.; WHITE, M. E. Epidemiologic features of equine Leptospira interrogans of human significance. Preventive Veterinary Medicine, Amsterdam, v. 36, n. 2, p. 153-165, 1998. http://dx.doi.org/10.1016/S0167-5877(98)00069-5

BATISTA, C. S. A.; AZEVEDO, S. S.; ALVES, C. J.; VASCONCELLOS, A. S.; MORAIS, M.; CLEMENTINO, I. J.; LIMA, F. S.; ARAUJO NETO, J. O. Soroprevalência de leptospirose em cães errantes da cidade de Patos, Estado da Paraíba, Brasil. Brazilian Journal of Veterinary Research and Animal Science, São Paulo, v. 41, n. 2, p. 131-136, 2004. http://dx.doi.org/10.1590/s1413-95962004000200009

BATISTA, C. S. A.; ALVES, C. J.; AZEVEDO, S. S.; VASCONCELLOS, A. S.; MORAIS, Z. M.; CLEMEMTINO, I. J.; ALVES, F. A. L.; LIMA, F. S.; ARAÚJO NETO, J. O. Soroprevalência e fatores de risco para a leptospirose em cães de Campina Grande, Paraíba. Arquivo Brasileiro de Medicina Veterinária e Zootecnia, Belo Horizonte, v. 57, supl. 2, p. 179-185, 2005. http://dx.doi.org/10.1590/S010209352005000800008

BOECHAR, J. U. D.; MACHADO, P. J. Prevalência da leptospirose canina no Brasil. Revista Veterinária SER, Rio de Janeiro, v. 1, n. 1, p. 40-47, 2004.

BOLIN, C. A. Diagnosis of leptospirosis: A reemerging disease of companion animals. Seminars in Veterinary Medicine and Surgery, Small Animal, Philadelphia, v. 11, n. 3, p. 166-171, 1996.

BRASIL, Manual de Leptospirose. Ministério da Saúde. Fundação Nacional de Saúde. Centro Nacional de Epidemiologia. Coordenação de Controle de Zoonoses e Animais Peçonhentos. Programa Nacional de Leptospirose. $2^{a}$ ed. rev. Brasília: Fundação Nacional de Saúde. 1995. 98p.

BRITO, J.; PRUDENTE, T. D. Mapeamento do uso da terra e cobertura vegetal do município de UberlândiaMG, utilizando imagens ccd/cbers2. Caminhos da Geografia, Uberlândia, v. 13, n. 15, p. 144-153, 2005.

FERNANDES, A. R. F.; FERNANDES, A. G.; ARAÚJO, V. J. A.; HIGINO, S. S. S.; SILVA, M. L. C. R.; ALVES, C. J.; AZEVEDO, S. S. Soroepidemiologia da leptospirose canina na região metropolitana de Natal, estado do Rio Grande do Norte. Brazilian Journal of Veterinary Research and Animal Science, São Paulo, v. 50, n. 3, p. 226-232, 2013. http://dx.doi.org/10.11606/issn.1678-4456.v50i3p226-232

JASZCZERSKI, D. C. F. C. Cinética da resposta imune humoral em cães imunizados com Leptospira interrogans sorovares icterohaemorragiae, canicola, pomona e grippotyphosa. 2005. $82 \mathrm{f}$. Dissertação (Mestrado em Patologia) - Setor de Ciências Agrárias, Universidade Federal do Paraná, Curitiba, 2005. 
LANGONI, H.; PIMENTEL, V. L.; SILVA, A. V.; LUCHEIS, S. B.; DENARDI, M. B. Avaliação da dinâmica de anticorpos pós-vacinais contra Leptospira spp. em cães vacinados pela prova de SAM. ARS Veterinária, Jaboticabal, v. 18, n. 1, p. 54-61, 2002.

MAGALHÃES, D. F.; SILVA, J. A.; MOREIRA, E. C.; WILKE, V. M. L.; HADDAD, J. P. A.; MENESES, J. N. C. Prevalência de aglutininas anti-Leptospira interrogans em cães de Belo Horizonte, Minas Gerais, 2001 a 2002. Arquivo Brasileiro de Medicina Veterinária e Zootecnia, Belo Horizonte, v. 58, n. 2, p. 167-174, 2006. http://dx.doi.org/10.1590/S0102-09352006000200004

MELLO, L. P. P.; MANHOSO, F. F. R. Aspectos epidemiológicos da leptospirose canina no Brasil. Unimar Ciências, Marília, v. 16, n.(1-2), p. 27-32, 2007.

QUERINO, A. M. V.; DELBEM, A. C. B.; OLIVEIRA, R. C.; SILVA, F. G.; MULLER, E. E.; FREIRE, R. L.; FREITAS, J. C. Fatores de risco associados à leptospirose em cães do município de Londrina-PR. Semina: Ciências Agrárias, Londrina, v. 24, n. 1, p. 27-34, 2003. http://dx.doi.org/10.5433/1679-0359.2003v24n1p27

SILVA, W. B.; SIMÕES, L. B.; LOPES, A. L. S.; PADOVANI, C. R.; LANGONI, H.; MODOLO, J. R. Avaliação de fatores de risco de cães sororreagentes à Leptospira spp e sua distribuição espacial, em área territorial urbana. Brazilian Journal of Veterinary Research and Animal Science, São Paulo, v. 43, n. 6, p. 783-792, 2006.

THRUSFIELD, M. Epidemiologia Veterinária. 2.ed. São Paulo: Roca, 2004. 556p.

VIEGAS, S. A. R. A.; TAVARES, C. H. T.; OLIVEIRA, E. M. D.; DIAS, A. R.; MENDONÇA, F. F.; SANTOS, M. F. P. Investigação sorológica para leptospirose em cães errantes na cidade de Salvador - Bahia. Revista Brasileira de Saúde e Produção Animal, Salvador, v. 2, n. 1, p. 21-30, 2001. 